\title{
Pemberdayaan Masyarakat Berbasis Multikultural di Majelis Taklim An Najach Magelang
}

\author{
Imamul Huda \\ Universitas Muhammadiyah Surakarta, Indonesia \\ imam.bawen@yahoo.com
}

\begin{abstract}
This research aims to describe the lecture of An Najach majelis taklim and its function for people empowerment activities. The research method uses qualitative-descriptive methods through the interview, observation, and documentation. The place of the research is at An Najach majelis taklim located in An Najach Islamic boarding school in Magelang. The results showed that first, the lecture materials are normative, emphasizing individual piety and not prioritizing issues related to living together in pluralism and multiculturalism; second, in addition to multicultural values, religious lectures contain some anti-multicultural values, such as truth claims, prejudices, stereotypes against other groups, stigma and judgment, and hate speech; and third, An Najach represents the capable majelis taklim to empower people in the spiritual, economic, educational, and social aspects. This research recommends the importance of professionalism in managing majelis taklim and good communication with the audience and people. This research enriches studies on the development of Islamic societies, especially in people empowerment based on majelis taklim.
\end{abstract}

Keywords: An Najach; Empowerment; Majelis Taklim; Multicultural

\begin{abstract}
Abstrak
Penelitian ini bertujuan untuk mendeskripsikan pengajian di majelis taklim An Najach serta fungsi dan perannya sebagai tempat kegiatan pemberdayaan masyarakat. Riset ini menggunakan metode penelitian kualitatif deskriftif dan analisis isi. Metode penelitian menggunakan metode deskriptif kualitatif melalui wawancara, observasi, dan dokumentasi. Tempat penelitian adalah majelis taklim An Najach yang bertempat di pondok pesantren An Najach Magelang. Hasil penelitian menunjukkan; Pertama, materi ceramab bersifat normatif, menekankan pada kesalehan individual dan kurang mengedepankan isu-isu yang terkait dengan bidup bersama dalam pluralisme dan multikultural. Kedua, di samping nilai-nilai multikultural, ceramah juga menyampaikan nilai-nilai anti-multikultural, semacam klaim kebenaran, prasangkal prejudice, stereotip terhadap kelompok lain, stigma dan penghakiman, dan hatred speeches atau ceramah mengandung pesan kebencian. Ketiga, An Najach merepresentasikan majelis taklim yang mampu memberdayaan masyarakat dalam bidang spiritual keagamaan, ekonomi, pendidikan, dan sosial kemasyarakatan. Penelitian ini merekomendasikan pentingnya profesionalisme dalam mengelola majelis taklim dan komunikasi yang baik dengan jamaab dan masyarakat. Penelitian ini memperkaya kajian tentang pengembangan masyarakat Islam khususnya dalam pemberdayaan masyarakat berbasis majelis taklim.
\end{abstract}

Kata kunci: An Najach; Majelis Taklim; Multikuktural; Pemberdayaan

Permalink/DOI: https://doi.org/10.18326/infsl3.v13i2.253-278 


\section{Pendahuluan}

Kewajiban belajar dan mencari ilmu tidak mengenal tempat, umur dan waktu. Kapan saja, di mana saja dan kepada siapa saja, seseorang dapat melakukan kewajiban tersebut. Ketika lembaga formal seperti sekolah/madrasah/ perguruan tinggi mengharuskan persyaratan yang tidak mungkin dipenuhi seseorang, maka dibutuhkan tempat dan waktu belajar yang bisa menampungnya. Salah satu tempat tersebut adalah majelis taklim yang pada umumnya lahir dari masyarakat, oleh masyarakat dan untuk masyarakat.

Majelis taklim dapat tumbuh dan bermunculan kapan saja dan di mana saja baik di tempat ibadah, perkantoran, perumahan, pondok pesantren dan tempat-tempat umum lainnya. Imam besar masjid Istiqlal Jakarta; Nasaruddin Umar (2018) menyatakan jumlah majelis taklim di Indonesia pada tahun 2018 kurang lebih sebanyak 250.000 buah. Sebagian besar majelis taklim mengambil tempat di masjid/mushola, karena menjadi tempat berkumpulnya masa, basis dimulainya instruksi dan menjadi tempat pembelajaran yang efektif (Zaimeche, 2002). Umar menegaskan bahwa jumlah majelis taklim yang banyak tersebut belum berbanding lurus dengan peningkatan kualitas masyarakat Islam. Kualitas kehidupan masyarakat tidak terletak pada jumlah/kwantitas majelis taklim, melainkan bagaimana upaya memberdayakan majelis taklim sebagai pusat pemberdayaan masyarakat.

Dalam konteks multikulturalisme, majelis taklim dapat menjadi media dakwah mulikultural, yaitu gerakan dakwah dengan memberikan ruang pemahaman keagamaan yang variatif, tidak tunggal, dan beragam. Dakwah yang berusaha membentuk sikap toleransi dan tidak mempertentangkan ragam agama, aliran agama, dan ragam pemahaman agama. Dakwah yang tidak hanya mementingkan peningkatan kuantitas tetapi dakwah yang melakukan perbaikan kualitas keimanan.

Penelitian ini bertujuan untuk pertama, mengidentifikasi lingkup materi ceramah majelis taklim An Najach Magelang dalam aspek-aspek multikultural dan anti-multikultural yang disampaikan dalam majelis taklim; kedua, mengidentifikasi optimalisasi fungsi majelis taklim AN Najach Magelang sebagai pusat kegiatan 
pemberdayaan masyarakat dalam berbagai macam aspek.

Kegiatan pemberdayaan masyarakat berbasis majelis taklim dalam penelitian ini dapat dimaknai sebagai gerakan majelis taklim sebagai kekuatan sentral yang melibatkan partisipasi jamaah, pengurus majelis taklim dan masyarakat yang telah berhasil menjadikan majelis taklim sebagai ikon destinasi religi sekaligus mampu menjadi penggerak kegiatan pemberdayaan masyarakat dalam aspek spiritual, aspek pendidikan, aspek ekonomi dan sosial kemasyarakatan sehingga mampu meningkatkan kemandirian, kesejahteraan dan peningkatan kualitas kehidupan secara lebih baik.

\section{Majelis Taklim, Halaqah, Zawiyah}

Majelis taklim berasal dari akar kata bahasa Arab, terdiri atas dua suku kata yakni majelis berarti "tempat" dan taklim yang berarti "mengajar", meskipun frase ini tidak dikenal secara umum di negeri Arab Saudi (Winn, 2012). Jadi secara bahasa, majelis taklim mempunyai makna "tempat belajar-mengajar". Kemenag (2008: 3) mendefinisikannya sebagai lembaga pendidikan Islam yang waktu belajarnya berkala, teratur, tetapi tidak setiap hari seperti di sekolah, namun jamaah hadir atas kesadaran sendiri tidak merupakan kewajiban yang memaksa karena dianggap suatu kebutuhan rohani mereka.

Hanun Asrohah (1999) berpendapat bahwa majelis taklim adalah suatu lembaga yang menyelenggarakan tempat pelaksanaan belajar mengajar agama Islam. Senada dengan Asrohah, Hasbullah (1995) mendefinisikan majelis taklim adalah suatu tempat untuk melaksanakan pengajaran atau pengajian Islam. Sedangkan definisi majelis taklim menurut Harizah Hamid (1991) adalah suatu wadah atau organisasi yang membina kegiatan keagamaan yaitu agama Islam. Ramayulis (1994) memperkuat ketiga pendapat tersebut dengan pernyataan bahwa majelis taklim adalah lembaga pendidikan non formal untuk memberikan pengajaran agama Islam. Dengan demikian majelis taklim adalah suatu lembaga pendidikan non formal dan merupakan salah satu tempat untuk melaksanakan kegiatan-kegiatan agama Islam seperti pengajaran nilai-nilai ajaran agama Islam melalui pengajian. 
Tetapi ada fakta menarik, yaitu istilah majelis taklim ternyata hanya ada di Indonesia. Di negara lain tidak dikenal istilah majelis taklim sebagaimana diungkap Ketua Lembaga Bahtsul Masail Nahdhatul Ulama (LBMNU) Zulfa Mustafa. Nasrul (2018) menjelaskan bahwa istilah majelis taklim di negara-negara Arab disebut dengan halaqah dan di kalangan sufi disebut dengan istilah zawiyah. Ketiga kata/istilah tersebut mendeskripsikan sekumpulan orang Muslim untuk belajar dan memahami ajaran agama Islam baik dari aspek teologi, filsafat, maupun tasawuf.

Sebagai lembaga pendidikan tertua dalam Islam -meskipun tidak disebut majelis taklim- namun pengajian nabi yang berlangsung secara sembunyi-sembunyi di rumah Arqom bin Abil Arqom dapat dianggap sebagai majelis taklim. Pada periode Madinah, ketika Islam telah menjadi kekuatan nyata dalam masyarakat, maka penyelenggaraan pengajian berkembang pesat. Dengan cara ini nabi berhasil menyiarkan agama Islam dan membentuk karakter ketaatan umat (Arifin, 1993). Di puncak kejayaan Islam, terutama pada saat Bani Abbasiyah berkuasa, majelis taklim selain dipergunakan tempat menuntut ilmu, juga menjadi media para ulama dan pemikir untuk menyebarluaskan hasil penemuan dan ijtihadnya. Dapat dikatakan bahwa para ilmuwan Islam dalam berbagai bidang ilmu ketika itu merupakan produk dari majelis taklim (Huda, 1984).

\section{Penceramab Menentukan "Trade Mark" Majelis Taklim}

Terdapat tiga komponen di dalam majelis taklim yaitu penceramah, jamaah dan materi ceramah. Penceramah adalah komponen terpenting sebagaimana guru adalah instrumen paling penting dalam implementasi kurikulum di sekolah. Materi ceramah tidak jauh berbeda dengan kurikulum, dalam berbagai bentuknya hanyalah sebuah teks dan oleh karena itu guru adalah yang benarbenar menentukan cara membaca dan menafsirkannya (Zainiyati, 2016). Dalam konteks Indonesianisme dan Islamisme, Maulana (2017) menegaskan bahwa guru agama melayani sebagai garda depan toleransi yang kemudian dimanifestasikan ke dalam konteks sosial mereka. Narasumber pengajian/majelis taklim yang biasa disebut penceramah, ustadz, kiai atau pun tuan guru tidak jarang menentukan warna dan karakter suatu majelis taklim. 
Lembaga Survey Indonesia (LSI) juga menyimpulkan bahwa model transfer pengetahuan tentang Islam melalui tatap muka dengan guru agama merupakan media utama bagi warga. Keberadaan penceramah menjadi tulang punggung pemberian materi, dan menjadi orang yang paling dipercaya. Mayoritas warga menganggap guru agama (imam, kiai, ustaz, dll) yang ditemui di pengajian atau kelas adalah sumber paling dipercaya untuk mendapatkan pengetahuan tentang Islam (Savitri, 2016). Demikian juga materi ceramah dapat menentukan warna dan karakter suatu majelis taklim. Jika materi ceramah suatu majelis taklim sudah ditentukan dan terstruktur menjadi semacam kurikulum pengajian, maka panitia/pengelola majelis taklim pasti akan mencari penceramah yang kompeten dengan syarat menyesuaikan karakter majelis taklim karena pengelola tidak ingin kehilangan karakter majelis taklim.

Pendapat ini diperkuat dengan karya Alfisyah (2009) yang menganalisis tentang materi majelis taklim dan mendukung pembentukan etika dan tingkah laku sehingga berperan penting dalam proses transformasi. Materi pengajian bermuatan nilai-nilai yang berhubungan semangat untuk mengumpulkan kekayaan, kewirausahaan, kebebasan berusaha, kemajuan, dan kesetaraan antara laki-laki dan perempuan selaras dengan karakteristik sosiokultural pesisir yang melekat dalam kehidupan masyarakat Banjar. Alasan inilah yang membuat pengajian di Banjar selalu menarik minat banyak orang dan berhasil bertahan selama berabadabad hingga sekarang.

\section{Problem Majelis Taklim}

Secara umum problem yang dihadapi majelis taklim adalah masalah isi materi dan penyampaian pidato yang kurang menarik, kurang memperhatikan relevansi materi ceramah dengan masalah aktual atau kebutuhan lingkungan. Selain itu, daya analisis terhadap situasi dan konsisi serta kemampuan mencari solusi atas masalah belum tepat, apa adanya dan belum sistematis (Nashrul, 2018).

Selain adanya beberapa problem majelis taklim tersebut, terdapat majelis taklim yang menyampaikan kajian dan membahas tentang sikap intoleransi dan anti multikultural di dalam majelis taklim. Hal ini disebabkan semangat berdakwah yang tinggi dari 
para penceramah seringkali dinodai dengan cara menjelek-jelekkan agama, aliran dan golongan orang lain (Baidhawy, 2010). Hasil kajian lainnya, pertama adalah sosialisasi ajaran keagamaan di tingkat akar rumput lebih banyak dikuasai oleh juru dakwah yang kurang peka terhadap pluralitas dan multikultural.

Problem lainnya adalah keberadaan organisasi-organisasi keagamaan yang cenderung mementingkan peningkatan kuantitas tetapi dakwah yang melakukan perbaikan kualitas keimanan kurang menjadi perhatian (Qorib, 2018). Demikian juga sikap agresif dan fanatik para pemeluk dan tokoh agama dalam mendakwahkan ajarannya (Sulaiman, 2016), keduanya bisa mengancam toleransi. Beberapa majelis taklim berbasis masjid juga tidak jarang diisi dengan berbagai ceramah anti multikultural dan intoleransi, sebagaimana yang terjadi di Masjid Komo Dalam Manado (Taufani \& Wekke, 2017). Taufani menyebutkan sentimen anti aliran/golongan lain dan klaim atas kebenaran suatu kelompok agama di Manado terjadi karena adanya persaingan dan perebutan lahan ekonomi, perebutan kekuasaan dan pengaruh di antara para mubaligh.

\section{Peran Majelis Taklim Dalam Pemberdayaan Masyarakat}

Konsep pemberdayaan diartikan sebagai proses melepaskan situasi atau keadaan ketidakmampuan, ketidakberdayaan, kehilangan, ketersisihan, dan hal-hal yang berkaitan dengan kelemahan. Maka pemberdayaan maksudnya adalah "mengubah dari yang tidak mampu menjadi mampu" atau mengubah dari yang lemah/tidak berdaya menjadi kuat/berdaya". Pemberdayaan adalah suatu cara dimana komunitas, organisasi, dan rakyat diarahkan agar mampu menguasai kehidupannya (Zulfa, 2015). Dalam konteks majelis taklim, majelis taklim yang memberdayakan masyarakat adalah majelis taklim yang mampu menguatkan masyarakatnya ke arah lebih baik. Pendek kata, majelis taklim diharapkan menjadi bagian tak terpisahkan dari pencapaian kesejahteraan umat.

Kegiatan pemberdayaan masyarakat berbasis majelis taklim dimaknai sebagai gerakan majelis taklim sebagai kekuatan sentral yang berpusat pada partisipasi jamaah, masyarakat dan pengurus majelis taklim. Kegiatan tersebut mampu menjadi ikon destinasi religi di suatu daerah yang mampu menjadi penggerak 
kegiatan pemberdayaan. Kegiatan tersebut mampu meningkatkan kemandirian, kesejahteraan dan peningkatan kualitas kehidupan secara lebih baik.

Penelitian mengenai peranan majelis taklim dalam pemberdayaan masyarakat Islam, telah dilakukan oleh Afriadi (2018) di Bangka Balitung. Berbagai bentuk pemberdayaan yang telah dilaksanakan antara lain; Pemberdayaan Ruhaniah, Pemberdayaan Intelektual, Pemberdayaan Sosial, Pemberdayaan Politik. Adapun fungsi majelis taklim dikemukakan dalam karya Minangsih (2014) yaitu tentang fungsi dan peran majelis taklim yang sangat efisien untuk dakwah Islam. Fungsi majelis taklim sejak zaman Nabi hingga sekarang adalah sama yaitu: tempat belajar-mengajar dalam rangka meningkatkan pengetahuan, pemahaman, dan pengamalan ajaran Islam, lembaga pendidikan dan keterampilan, wadah pengembangan kepribadian serta pembinaan keluarga dan rumah tangga sakinah mawaddah wa rohmah.

Sementara Ahmad Sarbini (2010) menjelaskan fungsi majelis taklim sebagai media internalisasi nilai-nilai keislaman. Hal senada diungkap Syukron Djazilan (2019) yang menjelaskan fungsi majelis taklim sebagai media internalisasi nilai-nilai keislaman. Menurut Nur Setiyawati (2012), keberadaan majelis taklim telah membawa manfaat dan kemaslahatan bagi masyarakat, khususnya bagi wanita muslimah. Hal ini (majelis taklim) disebut dengan Islamisasi sebagai cara memperbaiki masyarakat agar bisa berkembang maju sebagaimana dikatakan Larry Paston (1992) dan BJ Boland (1997).

Selain mempunyai beberapa fungsi dalam pendidikan agama dan dakwah Islam, majelis taklim juga memiliki banyak peran aktif di berbagai kehidupan sosial. Seperti majelis taklim Az Zahra Gondoriyo Ngaliyan Semarang yang mampu bertransformasi menjadi lembaga amil zakat untuk kesejahteraan sosial-ekonomi masyarakat. Perannya sebagai lembaga amil zakat lebih dirasakan manfaatnya dari hanya sekedar majlis taklim. Majelis taklim AzZahra mengadakan berbagai kegiatan positif untuk mendukung cita-cita tersebut, di antaranya adalah workshop, kajian-kajian, studi banding dan sebagainya. (Amin, 2016).

Tidak kalah menarik dari majelis taklim Az-Zahra Ngaliyan 
Semarang, adalah pengajian/majelis taklim di Weleri Kendal. Pengajian Ahad pagi pukul 06.00-07.00 di kantor kawedanan Weleri adalah salah satu Amal Usaha Muhammadiyah (AUM) yang dikelola oleh Majelis Tabligh PCM Weleri. Keberadaan pengajian tersebut semakin berkembang dan berdaya seiring dengan bertambahnya jumlah jamaah yang berasal dari desa-desa yang ada di seluruh Kecamatan Weleri Kabupaten Kendal. Tidak ketinggalan para pedagang turut hadir untuk mengaji sambil berjualan. Majelis taklim tersebut mempunyai peran yang sangat besar terhadap perkembangan dan pemberdayaan persyarikatan Muhammadiyah Kendal. Hingga saat ini dapat berkembang dengan pesat secara horizontal maupun vertikal. Banyak berdiri AUM (Amal Usaha Muhammadiyah) seperti sekolah dari pendidikan usia dini hingga perguruan tinggi, panti asuhan, Rumah Sakit, panti jompo dan peningkatan kuantitas cabang maupun ranting Muhammadiyah (Rinanto, 2016). Hasil infaq setiap pelaksanaan pengajian mencapai puluhan juta. Hingga saat ini, jamaah yang menghadiri majelis taklim tersebut mencapai kurang lebih 2000 orang.

Pemberdayaan dalam sosial ekonomi juga sangat penting bagi anggota yang akan memperlancar aktivitas majelis taklim secara lebih luas. Hal inilah yang dilakukan oleh beberapa majelis taklim di Kelurahan Banten Kota Serang seperti yang diungkap oleh Muhammad Syafar (2018). Beberapa majelis taklim yang berlokasi di Kelurahan Banten, Kecamatan Kesemen - Kota Serang, melakukan kegiatan usaha ekonomi dalam skala kecil, yaitu: industri pengolahan makanan. Kegiatan tersbut berupa pelatihan dan pendampingan untuk meningkatkan life skills bagi komunitas majelis taklim, yaitu pelatihan pengolahan ikan dalam upaya mengembangkan usaha produktif. Majelis taklim melatih masyarakat untuk mengolah ikan menjadi makanan variatif, melatih masyarakat untuk mengolah ikan menjadi makanan sehat, dan melatih masyarakat untuk mengemas hasil olahan ikan menjadi menarik.

\section{Multikultural; Peluang dan Tantangan}

Dalam perspektif multikulturalisme, Gollnick (1983) menjelaskan "keadaan" dimana seseorang telah menguasai pengetahuan dan mengembangkan keterampilan (skill) yang diperlukan untuk merasakan bahagia dan berkomunikasi dengan 
baik kepada orang lain. Konsep Gollnick ini memberi ruang untuk hidup bersama (living together) antar individu dengan latar belakang yang berbeda-beda. Ricci (2002) melengkapinya dengan unsurunsur keragaman (diversity), kesetaraan (equality), dan penghargaan (respect). Senada dengan Ricci, Blum (2001) menyebutkan tiga nilai dalam multikulturalisme: menegaskan identitas kultural seseorang, menghormati, mau memahami dan belajar tentang kebudayaankebudayaan lain; serta menilai dan merasa senang dengan perbedaan kebudayaan itu sendiri.

Sementara itu, Paul C. Gorski (2010) berpendapat, bahwa pendidikan multikultural mencakup tentang keadilan sosial, keadilan pendidikan, pedagogi kritis, dan dedikasi untuk memberikan pengalaman pendidikan kepada semua siswa. Dalam perspektif Islam, Sachedina (1990) memetakan dimensi-dimensi sosial politik dalam doktrin Islam dan praktiknya ke dalam tiga kelompok: nilai kesatuan kemanusiaan (the unity of humankind), berlomba berbuat baik (competition in good works), dan memaafkan orang lain (forgiveness toward humankind).

Masyarakat dan bangsa Indonesia disebut sebagai masyarakat multikultural karena terdiri dari berbagai ragam etnis, budaya, agama, aliran agama, aspirasi politik, sosial, dan lain-lain. Kondisi tersebut memiliki potensi konflik apalagi jika ditambah himpitan masalah ekonomi, sosial serta budaya (Miftah, 2016). Karena masalah konflik tidak lepas dari kehidupan multikultural dan kehidupan multikultural manusia merupakan potensi konflik dalam berbagai hal (Ledang, 2016). Konflik antar individu maupun antar kelompok adalah akibat dari adanya perbedaan perspektif, kepentingan, dan tujuan hidup di antara mereka. Konflik bisa disebabkan dari masalah yang sangat sederhana atau kecil sampai dengan masalah yang kompleks atau besar.

Salah satu upaya untuk memperjuangkan multikulturalisme adalah melalui pendidikan multikultural. Pendidikan multikultural adalah upaya untuk mencegah konflik, (Nakaya, 2018) karena konflik yang terjadi saat ini bukan lagi sekedar fenomena atau gejala, tetapi sudah menjadi realitas dalam kehidupan masyarakat sehari-hari. James Banks (1993) mendefinisikan pendidikan multikultural sebagai 
pendidikan untuk people of color. Demikian pula dengan Sleeter (1994) yang menjelaskan bahwa pendidikan multikultural adalah sebuah proses yang dilakukan oleh lembaga pendidikan untuk menentang kelompok yang menindas. Pengertian-pengertian ini tidak sesuai dengan konteks pendidikan di Indonesia karena Indonesia memiliki konteks budaya yang berbeda dari Amerika Serikat. Definisi Banks di atas diperkuat oleh H.A.R Tilaar (2004), yang mengatakan bahwa dalam pendidikan multikultural tidak mengenal fanatisme dan fundamentalisme sosialbudaya termasuk agama.

Senada dengan pengertian di atas, Choirul Mahfud (2006) menyatakan bahwa pendidikan multikultural adalah mengakui realitas politik, sosial dan ekonomi setiap individu dalam masyarakat, menghormati dan menghargai budaya, ras, etnisitas, agama, status sosial, seksualitas dan gender, ekonomi dan pengecualianpengecualian dalam proses pendidikan. Sedangkan Ainul Yaqin (2005) menggunakan perbedaan-perbedaan kultural yang ada pada setiap siswa seperti perbedaan agama, ras, etnis, kelas sosial, gender,bahasa, kemampuan dan umur untuk dijadikan strategi dalam mengaplikasikan semua jenis mata pelajaran agar proses belajar menjadi mudah.

Pendidikan multikultural adalah strategi pendidikan yang memiliki tujuan untuk melatih dan membangun karakter siswa agar bersikap demokratis, humanis dan pluralis dalam lingkungan mereka (Ainul Yaqin, 2005). Melalui pendidikan multikultural diharapkan dapat membebaskan dirinya dari prasangka, bias dan diskriminasi atas nama apapun, baik itu agama, gender, ras, warna kulit, kebudayaan, maupun kelas sosial.

Rumusan tujuan pendikan multikultural oleh para pengkaji pendidikan multikultural di Indonesia diantaranya: 1) Membangun paradigma keberagaman inklusif 2) Menghargai keragaman bahasa 3) Membangun sensitif gender 4) Membangun pemahaman kritis terhadap perbedaan status sosial dan ketidakadilan 5) Konstryksi sikap anti deskriminasi 6) Menghargai perbedaan kemampuan 7) Menghargai perbedaan umur 8) Belajar hidup dalam perbedaaan 9) Membangun sikap saling pengertian 10) Menjunjung sikap saling menghargai 11) Membangun sikap saling percaya 12) Membangun 
sikap tebuka dalam berpikir 13) Menumbuhkan sikap apresiatif dan interdependensi 14) Resolusi konflik dan rekonsiliasi tanpa kekerasan.

Berdasarkan

pembahasan-pembahasan

tentang multikulturalisme, definisi dan tujuan pendidikan multikultural para tokoh pendidikan multikultural, maka dapat ditetapkan butirbutir/pokok-pokok karakter pendidikan multikultural yaitu: 1) keterampilan (skill) untuk merasakan bahagia dan berkomunikasi dengan baik kepada orang lain (Gollnick, 1983) ; 2) keragaman (diversity), kesetaraan (equality), penghargaan (respect) (Ricci, 2002); 3) nilai kesatuan kemanusiaan (the unity of bumankind), berlomba berbuat bail (competition in good works), memaafkan orang lain (forgiveness toward humankind) (Sachedina, 1990); 4) menentang kelompok yang menindas (Sleeter, 1994); 5) pendidikan untuk people of color (Banks, 1993); 6) tidak mengenal fanatisme dan fundamentalisme sosial-budaya agama, tidak mengenal adanya xenophobia (kebencian terhadap barang/orang asing), mengembangkan keterampilan sosial (social action) (Tilaar, 2009); 7) belajar untuk hidup bersama dalam perbedaan (learning to live together), rasa saling percaya (mutual trust), saling memahami (mutual understanding), saling menghargai (mutual respect), terbuka dalam berfikir, apresiasi dan interdependensi, resolusi konflik, rekonsiliasi nirkekerasan (Baidhawy, 2005); 8) pendidikan tanpa membedakan kelompok-kelompok gender, etnik, ras, budaya, strata sosial dan agama, mengakui realitas politik, sosial dan ekonomi masing-masing individu, interaksi sesama manusia/ mengembangkan seluruh potensi manusia, meliputi potensi religius, moral, intelektual, ekonomi,sosial, potensi kesopanan dan budaya/ menghargai pluralitas dan heterogenitas/menghargai dan menjunjung tinggi keragaman budaya, etnis, suku dan agama (Mahfud, 2006); 9) perbedaan kultural para siswa, keberagaman inklusif, menghargai keragaman bahasa, membangun sensitif gender, kritis terhadap ketidakadilan dan perbedaan status sosial, anti deskriminasi etnik, menghargai perbedaan kemampuan, menghargai perbedaan umur (Yaqin, 2005); 10) keadilan sosial, kesetaraan pendidikan, pedagogi kritis, dan dedikasi untuk memberikan pengalaman pendidikan (Gorski, 2010); 11) nilai-nilai demokratis, persamaan (equality), 
saling menghormati, saling menerima, keadilan social, memberangus praktik-praktek penindasan, mendapatkan persamaan pendidikan, mengembangkan kurikulum, reformasi sekolah yang komprehensif, pendidikan dasar untuk semua anak didik, menentang semua bentuk diskriminasi, prinsip- prinsip demokratis keadilan sosial (Suparta, 2008); 11) kesetaraan pendidikan (Zamroni, 2011); 12) mencegah konflik (Nakaya, 2013).

\section{Metode Penelitian}

Dengan menggunakan metoda deskriptif kualitatif peneliti memusatkan diri pada persoalan-persoalan aktual melalui pengumpulan data, susunan data, penjelasan data dan analisis data (Moleong, 2005). Sumber data primer didapatkan dari data yang dikumpulkan dalam bentuk wawancara dari informan yang dianggap punya peran penting dalam kegiatan pemberdayaan masyarakat berbasis majelis taklim. Sumber data lain yang digunakan yaitu observasi lapangan. Peneliti ikut serta menghadiri pengajian sebagai jamaah dan ditunjang dengan teknik dokumentasi berupa mengumpulkan dokumen-dokumen kegiatan majelis taklim yang telah dilaksanakan. Data-data diambil dari lapangan dengan mengikuti secara rutin pengajian pada hari Ahad dan Selasa. Secara fokus penelitian ini membahas majelis taklim An Najach yang memiliki peran dan fungsi memberdayakan masyarakat dalam beberapa aspek kehidupan.

Penelitian ini dilakukan di majelis taklim An Najach pada tahun 2019. Subyek penelitian adalah majelis taklim An Najach yang terletak di pondok pesantren An Najach Koripan Tegalrejo Kabupaten Magelang Jawa Tengah. Jumlah santri pondok pesantren An Najach saat ini 600 santri putra-putri. Sedangkan jumlah jamaah yang menghadiri majelis taklim An Najach kurang lebih 5000-7000 orang pada setiap hari Selasa malam dan 10.000-15.000 orang pada setiap hari Ahad pagi. Latar belakang jamaah beragam mulai dari kalangan Muhammadiyah, NU, MTA, salafi, hingga masyarakat awam non-partisan.

\section{Hasil dan Pembahasan}

Profil Majelis Taklim An Najach

Majelis taklim An Najach tidak berbeda dengan majelis taklim 
lainnya, materi ceramah yang disampaikan juga tidak berbeda dengan materi ceramah pada majelis taklim lainnya yaitu tentang; aqidah, syariah, akhlaq dan wawasan keislaman. Materi ceramah di pengajian majelis taklim An Najach secara umum menekankan pada kesalehan individu yang berkenaan dengan perilaku, sikap dan ajaran tasawuf dan tarekat, pentingnya persatuan umat Islam tanpa perpecahan golongan, dikhotomi ilmu agama dan ilmu umum, kriteria ulama/kiai dan masalah muamalah hutang piutang.

Tidak ada kurikulum yang tetap dalam majelis taklim An Najach meskipun sudah ditentukan materi pengajian yaitu pada Selasa malam tentang 73 golongan umat Islam dan pada Ahad pagi mengkaji tafsir al Quran. Abdul Mukti selaku penceramah tunggal membahas masalah kehidupan sehari-hari dengan menggunakan bahasa Jawa dicampur dengan bahasa Indonesia membuat suasana majelis taklim An Najach selalu meriah meskipun sesekali keluar kata-kata kasar dan ujaran kebencian dengan menggunakan bahasa Jawa.

Kegiatan majelis taklim An Najach dilaksanakan dua kali pengajian dan sekali istighotsah setiap pekan, yaitu pada hari Ahad pukul 07.00-09.00 dan pada hari Selasa pukul 19.00-21.00. Adapun kegiatan istighotsah dilaksanakan setiap hari Senin malam Selasa. Pelaksanaan pengajian selalu diikuti oleh puluhan ribu jamaah yang berasal dari berbagai kota dengan latar belakang bermacam-macam. Pedagang, petani, pegawai, guru/dosen, buruh hingga pejabat pemerintah. Kaya, miskin, laki-laki, perempuan, remaja, dewasa, anak-anak hingga lansia. Dari kaum nahdhiyin, Muhammadiyah, MTA, salafi hingga kaum awam non partisan. Jumlah jamaah pengajian yang hadir kurang lebih 5000-7000 orang pada setiap hari Selasa malam dan 10.000-15.000 orang pada setiap hari Ahad pagi. Pada penutupan pengajian sebelum bulan ramadhan tahun 2019 ini, jumlah pengunjung mencapai lebih dari 100.000 orang. Pihak panitia menjamu tamu dengan menyembelih 9 ekor sapi, memasak 1,3 ton beras dan menyediakan 80.000 bungkus nasi.

Majelis taklim An Najach memiliki beberapa kelebihan dan keunikan, antara lain :

Setiap pelaksanaan pengajian selalu diikuti ribuan bingga 
puluban ribu jamaah yang berdatangan dari berbagai kota dan terdiri dari berbagai lapisan dan latar belakang masyarakat.

Majelis taklim An Najach sering menyampaikan ceramah kontroversial dan materi yang mengandung intoleransi dan nilai-nilai anti-multikultural.

Majelis taklim An Najach tetap eksis meskipun sudah berumur 28 tahun dan tidak melabirkan tindakan intoleransi dan radikalisme dari para jamaabnya.

Wacana (discourse) teks-teks keagamaan yang disampaikan melalui forum-forum pengajian An Najach sangat mungkin berdampak atau berpotensi menimbulkan ketegangan antar kelompok keagamaan ketika terjadi perbedaan tafsir dan cara memahaminya. Demikian yang terjadi dengan Abdul Mukti, wacana pemikirannya dianggap telah menyinggung banyak umat Islam.

\section{Nilai Multikultural di Majelis Taklim An Najach}

Meskipun sering menyampaikan kata-kata kasar dan ujaran kebencian di dalam mejelis taklim, tetapi Mukti juga banyak menyampaikan materi ceramah yang mengandung nilai-nilai multikultural. Materi tersebut antara lain ajakan Mukti kepada para jamaah untuk menjalankan ajaran tasawuf, nasehat untuk berhatihati ketika berbaiat dengan mursyid tarekat. Mursyid thoriqoh harus hafal alquran dan alhadits, anjuran untuk banyak berbuat dan menghindari perdebatan dan nasehat tentang bantuan pemerintah dan pemberian orang lain. Pemberian uang dari pejabat lebih baik tidak diterima karena sifat barang tersebut masih remangremang/syubhat. Pemberian uang dari pemerintah, boleh diterima berdasarkan ayat:

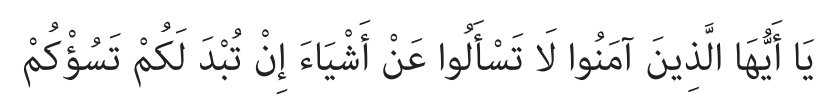

Mukti juga menjelaskan tentang materi ceramah yang menyinggung perasaan. Tidak dianjurkan putus asa dikarenakan sakit hati mendengar materi ceramah yang menyinggungnya, bahkan Mukti menegaskan hal tersebut merupakan petunjuk dari Allah. Tentang rezeki dan pekerjaan, Mukti menjelaskan bolehnya bekerjasama dengan Nashrani dan Yahudi dalam mata pencaharian. Yang pokok dalam hidup adalah beribadah meminta rezeki dari Allah, maka Allah akan memberi rezeki melalui pekerjaan. Jika 
seseorang ingin kaya maka harus bekerja, tapi tidak semua yang bekerja bisa menjadi kaya. Orang menjadi kaya karena rajin bekerja dan mendapat anugrah dari Allah, menjadi orang kaya karena kehendak Allah. Orang pandai karena rajin belajar dan mendapat anugerah Allah, menjadi pandai karena kehendak Allah. Manusia hanya diwajibkan bekerja tidak diperbolehkan menganggur. Bekerja adalah perintah agama Islam dan tidak boleh malu meskipun melakukan pekerjaan kasar.

Pentingnya persatuan umat muslim agar supaya tidak terpecah belah, dan larangan membuat kelompok dan golongan menjadi perhatian khusus Abdul Mukti. Di dalam berbagai kesempatan ceramah, Mukti selalu menekankan masalah persatuan umat muslim. Demikian juga dengan masalah fanatisme. Mukti selalu menjelaskan larangan bersikap fanatik golongan/kelompok dan keturunan karena semua manusia adalah sama kedudukannya di sisi Tuhan. Larangan membanggakan diri karena keturunan kiai, habaib dan pejabat. Tentang sholat berjamaah Mukti menjelaskan bahwa berhak menjadi imam sholat adalah orang yang mampu membaca kitab (klasik/kuning) dan mengerti hukum /syariat agama Islam meskipun tukang rumput atau tukang ojek. Anjuran untuk selalu/rajin mendatangi pengajian juga menjadi perhatiannya. Mukti menegaskan bahwa 'ngaji' sebagai bekal mati, niat ngaji yang benar adalah mencari bekal mati. Masalah lain yang berkaitan dengan hukum/syariat dan problem kehidupan sehari-hari dibahas secara detail, vulgar hingga tuntas meskipun kadang-kadang berkaitan dengan pornografi.

Nilai-nilai multikultural yang ditemukan dalam ceramah pembahasan syariat, tasawuf, persatuan umat, dan ajaran Islam adalah meliputi kesetaraan pendidikan, pedagogi kritis, dan dedikasi untuk memberikan pengalaman pendidikan (Gorsky, 2010), kesederajatan (egalitarianism) (Suparlan, 2002), pengakuan, penghargaan dan keadilan terhadap hak-hak individu maupun komunitasnya (Kymlicka, 1999), kesetaraan (equality) (Ricci, 2002), kritis terhadap perbedaan status sosial, memberikan prinsip- prinsip demokratis, dan keadilan sosial (Suparta, 2003), berlomba dalam kebaikan (competition in good works), memaafkan orang lain (forgiveness toward bumankind) (Sachedina, 1990), pendidikan 
tentang kehidupan bersama (living together), menumbuhkan sikap saling percaya (mutual trust), saling menghargai (mutual respect), berpikir positif (positive thinking), kedamaian (peace), terbuka dalam berfikir (Baidhawy, 2005), menjunjung tinggi agama dan potensi religius, moral, intelektual,ekonomi, sosial, kesopanan dan budaya (Mahfud, 2006).

\section{Potensi Intoleransi di Majelis Taklim An Najach}

Di samping nilai-nilai multikulturalisme, ceramah di majelis taklim An Najach juga menyampaikan nilai-nilai antimultikulturalisme, semacam klaim kebenaran (hanya golongannya yang benar), prasangka/prejudice dan stereotip (pandangan negatif tentang orang lain yang tidak sepaham), stigma dan penghakiman (pelabelan bahwa pihak lain itu negatif, salah, berdosa dan masuk neraka), arogansi kelompok (bahwa kelompoknya lebih baik daripada kelompok lain), dan hatred speeches atau ceramah mengandung pesan kebencian.

Pemikiran dan pernyataan yang disampaikan Abdul Mukti seringkali dipandang kontroversial dan menyebabkan munculnya 'ketersinggungan' masyarakat yang berekses terjadinya konflik terselubung (konflik bathin). Wacana (discourse) teks-teks keagamaan yang disampaikan melalui forum-forum pengajian sangat mungkin berdampak atau berpotensi menimbulkan ketegangan antar kelompok keagamaan ketika terjadi perbedaan tafsir dan cara memahaminya. Beberapa materi ceramah yang kontroversial dan intoleran adalah sebagai berikut;

\section{Perpecahan Umat Islam}

Mukti menegaskan bahwa masuk ke dalam atau menjadi bagian dari kelompok-kelompok keagamaan tertentu (NU/ Muhammadiyah/Darul Arqom/Al Irsyad dsb) adalah perilaku sesat karena sama halnya telah memecah belah umat Islam. Pernyataan ini direproduksi di setiap kesempatan pengajian, baik pengajian Selasa malam, Ahad pagi ataupun yang dapat dilihat dan didengarkan melalui rekaman youtube. Meskipun kajian materi dalam pengajian membahas sesuatu kemaslahatan, namun persoalan larangan mengikuti ormas keagamaan dan fanatisme golongan senanantiasa muncul. Dua persoalan tersebut menjadi 
jargon dan agenda yang mesti disuarakan dalam upaya melakukan gerakan amar ma'ruf nahi munkar. Membuat golongan-golongan/ firqoh menurut Abdul Mukti hukumnya adalah haram.

\section{Fanatisme Golongan/Kelompok}

Abdul Mukti menjelaskan bahwa orang yang fanatik terhadap ormas dan nasab (keturunan) akan masuk neraka dahulu sebelum dihisab. Orang fanatik nasab adalah orang yang membanggakan diri karena nasabnya, karena keturunan kiai/ ulama/wali. Padahal kiai/ulama dan keturunannya tidak ada jaminan masuk surga sebagaimana yang disampaikan;

"Tidak sedikit kiai yang masuk neraka, maka dari itu tidak selayaknya seseorang membanggakan diri sebagai keturunan kiai. Akan tetapi masalah tersebut tidak dijelaskan di masyarakat oleh para kiai karena pernyataan tersebut akan menjadi bumerang bagi mereka alias senjata makan tuan."

Kriteria kiai yang masuk surga menurutnya adalah al ulama warotsatul anbiya' yaitu ulama pengganti nabi yang memiliki sifat amanah, tabligh, sidiq dan fathonah;

\section{Ilmu Umum Versus Ilmu Agama}

Mencari ilmu agama hukumnya adalah wajib ain dan mencari ilmu umum adalah wajib kifayah. Anak yang belajar di sekolah (umum) sulit untuk menjadi anak sholeh. Pendidikan Islami adalah pendidikan agama. Pendidikan kafiri adalah pendidikan untuk mencari ilmu umum/mencari dunia yang berorientasi ke neraka. Abdul Mukti menambah keterangan bahwa yang dimaksud ilmu dunia adalah ilmu yang membuat manusia lupa akan Tuhan dan ilmu akhirat adalah ilmu yang membuat manusia ingat akan Tuhan dan dekat dengan Tuhan. Ilmu umum menjanjikan gelar dan pangkat yang tinggi tapi menjerumuskan ke neraka. Seorang muslim yang bodoh dalam urusan dunia, kelak di akhirat menjadi pandai karena akan diajari oleh Allah, demikian argumentasi Mukti.

\section{Ulama Buruk dan Ulama Baik}

Abdul Mukti menjelaskan bahwa kriteria yang harus dimiliki 
kiai adalah berilmu, beramal, berakhlaq, memiliki syajaab (keberanian), dan memiliki sakbiyyah (kedemawanan). Mukti menegaskan bahwa kiai dan ulama harus netral, tidak boleh mengikuti organisasi kemasyarakatan, dan tidak boleh aktif di partai politik. Kiai/ulama yang mondar-mandir keluar masuk istana menurut Mukti dapat mempercepat keluarnya dajjal. Kiai aktif di dunia politik berarti melanggar syariat Allah sama dengan perilaku kafir yaitu menuruti hawa nafsu. Bahkan dengan tegas Mukti menyamakan kiai yang masuk politik adalah kiai syetan bukan warotsatul anbiya' sama dengan pengkhianat agama.

Selain menyebut kiai syetan, Mukti juga menjelaskan bahwa banyak kiai yang mempertahankan kesalahan karena takut kehilangan pengikut/demi martabat padahal mereka mengetahui kesalahan tersebut tapi takut menyampaikan. Kiai akbrosh (bisu) adalah mereka yang tidak mau menjelaskan hukum secara hak dan jelas, tapi menyembunyikannya. Status seorang kiai akan sama dengan celeng (babi hutan) ketika hatinya dikuasai nafsu. Selanjutnya asu (anjing) sama dengan kiai yang takut tidak diundang kenduren karena takut dikatakan bid'ah. Kiai/ ulama yang mengajak ke partai politik adalah kiai ghofilun, ulamaul ghofilun, kiai upil (ingus). Begitu juga dengan kiai yang mengutamakan ilmu umum disebut oleh Mukti sebagai kiai bajingan (penjahat ). Pada saat ini, tokoh agama di masyarakat didominasi oleh kiai tahlil, kiai berkatan (memimpin selamatan), ulama karbitan (tidak mampu membaca kitab dan memahami hukum Islam) dan ahli ilmu tapi tidak melaksanakan ilmunya..

\section{Life Style dan Asuransi}

Dalam menjalani kehidupan dunia saat ini, Abdul Mukti banyak memberikan nasihat agar supaya manusia berhati-hati dan tidak terjerumus ke dalam kesenangan duniawi belaka. Beberapa nasihat tersebut antara lain; larangan bermegahmegahan, larangan berdandan model artis, hukum hiburan dan kesenian, asuransi dan BPJS. Mukti mengatakan bahwa tidak ada artis yang masuk surga. Ada sebagian yang masuk surga namun dengan syarat akhir hidupnya beriman dan bertaubat nashuha tapi harus masuk neraka dahulu selama ratusan tahun. 
Mencukur alis, suntik inplant/silicont, menyemir rambut dan tato hukumnya haram. Tato tobatnya tidak diterima kecuali taubat nasuha dan menghapus tatonya. Orang bertato dosanya terus mengalir ke orang tua yang sudah meninggal. Orang bertato mandi jinabatnya tidak syah karena najis. Dan semua jenis berhias tersebut hukumnya adalah haram.

Semua jenis musik (orkes/dangdut/wayang/gambus/ samroh dan lain-lain) menurut Mukti hukumnya adalah haram. Termasuk juga menyimpan alat-alat musik. Dengan tegas Mukti menyampaikan bahwa hukum nyanyian adalah haram, upahnya haram, dan orang yang melihatnya itu juga haram. Menyanyi adalah sama dengan memanggil syetan. Hukum seni membaca al-Quran dalam musabaqah tilawatil qur'an (MTQ) juga haram, karena al-Quran diturunkan untuk dibaca dan diamalkan tidak untuk pertandingan (musabaqab) berarti dholim. Multi juga menegaskan bahwa BPJS dan semua asuransi adalah haram.

Hatred speeches atau ceramah mengandung pesan kebencian tampaknya cukup menonjol di pengajian majelis taklim An Najach. Dengan alasan berbicara/berceramah di rumah sendiri, Abdul Mukti merasa mendapatkan kebebasan berbicara sebagai hak warga negara. Ceramah intoleransi dan nilai-nilai anti-multikultural juga ditemukan di majelis taklim ini semacam klaim kebenaran, prasangka/prejudice, stigma dan stereotip terhadap kelompok lain, penghakiman dan arogansi kelompok.

\section{Over Generalized Beliefs}

Seorang yang berpikir negatif belum tentu mau bertindak intoleran (Powel \& Clarke, 2013). Hal ini bermakna bahwa orang yang melakukan tindakan intoleran adalah yang memiliki pandangan stereotip/negatif kepada orang. Tapi sebaliknya, seorang yang hanya berpikir negatif boleh jadi bukan seorang yang intoleran. Masalah toleran-intoleran adalah berkaitan dengan action bukan sekedar pikiran, apalagi sebuah aturan. Menurut Cohen (2004) toleran adalah tindakan yang disengaja oleh seseorang dengan cara menahan diri dari campur tangan (menentang) perilakunya dalam situasi keragaman, sekalipun aktor percaya dia memiliki kekuatan untuk mengganggu. Istilah toleran menurut Cohen (2004) yaitu sikap 
seseorang menahan diri yang tidak menentang perilaku keragaman meskipun dia memiliki kekuatan untuk mengganggu.

Russell Powell dan Steve Clarke (2013) menjelaskan sikap "tidak-mengganggu" adalah esensi dari toleransi. Dan sikap tidak-mengganggu ini harus sifatnya adalah direct, yaitu "tidakmengganggu-secara langsung”. Meskipun tidak setuju dan memiliki kekuatan untuk melarang tapi memilih untuk tidak mengganggunya. Maka dalam perspektif Powell dan Clark, seorang yang toleran adalah yang sengaja menahan dirinya dari tindakan tidak setuju serta membolehkan tanpa gangguannya.

Intoleransi Abdul Mukti dalam hal ini adalah ketidakmampuannya menahan diri tidak suka kepada orang lain, sikap mencampuri dan atau menentang sikap atau keyakinan orang lain yang diungkapkan dalam ceramahnya, akan tetapi tidak mengganggu orang lain. Sikap intoleransi Abdul Mukti tersebut disebabkan oleh simplifikasi-palsu atau "prasangka yang berlebihan" (over generalized beliefs) yang mencakup stereotip terhadap "pihak lain yang direndahkan", sikap muak atau tidak suka yang mendalam akan tetapi tidak melakukan tindakan negatif terhadap anggota kelompok lain, baik secara interpersonal maupun dalam hal kebijakan politik-sosial (Hunsberger,1995).

\section{Pemberdayaan Masyarakat Berbasis Majelis Taklim}

Bentuk pemberdayaan masyarakat berbasis multikultural di majelis taklim An Najach meliputi beberapa aspek diantaranya:

Pemberdayaan Aspek Spiritual

Aspek paling penting dalam hidup adalah aspek spiritual. Aspek ini yang menuntun, membimbing, mengarahkan dan memberi petunjuk dalam mengambil berbagai keputusan dalam hidup. Aspek ini mencakup 3 hal pokok yaitu mengenal Allah, Rasul, Islam. Aspek spiritual/keagamaan merupakan core dari kegiatan majelis taklim. Inti kegiatan keagamaan yang utama adalah kegiatan ngaji itu sendiri. Sebagaimana yang disampaikan Mukti bahwa ngaji adalah bekal untuk mati.

Kehadiran jamaah ke majelis taklim adalah untuk memahami ajaran agama melalui tiga kegiatan. Pertama, kegiatan pengajian 
dua kali sepekan yang selalu diikuti ribuan jamaah. Laki-lakiperempuan, tua/muda, anak-anak/remaja, miskin/kaya, petani, pedagang, kiai/santri, rakyat jelata hingga pejabat berbaur menjadi satu. Tidak ada tempat duduk khusus untuk undangan, semua jamaah disamakan. Kedua, kegiatan istighotsah setiap Senin malam yang diikuti ribuan orang meskipun tidak sebanyak jamaah pengajian. Membaca kalimat thoyyibah, berdoa dan berdzikir dipimpin langsung Abdul Mukti membuat jamaah mendapatkan ketenangan dan kepuasan batin tersendiri. Ketiga, kegiatan rutin membaca doa bersama setiap pengajian, membaca bacaan sholawat nabi, dan melaksanakan sholat isya' berjamaah setelah pengajian Selasa malam adalah upaya pemberdayaan masyarakat dalam aspek spiritual.

\section{Pemberdayaan Aspek Sosial}

Keberadaan pengajian dan istighotsah memberikan dampak positif terhadap kehidupan sosial masyarakat. Dengan berkumpulnya ribuan manusia di suatu tempat, dengan sendirinya akan menjadi motor pemberdayaan, baik sengaja maupun tidak. Bentuk pemberdayaan aspek sosial berbasis majelis taklim An Najach saat ini diantaranya: (1) Radio Dakwah/siaran langsung pengajian, (2) Klinik dan Balai Kesehatan Gratis, (3) Parkir luas yang aman dan toilet bersih gratis (4) Pengajian bebas infaq/ tidak disediakan kotak infaq (5) Biaya pendidikan pesantren murah; 10.000/bulan, (6) Infaq/pemberian Tunjangan Hari Raya untuk jamaah, masyarakat dan tokoh masyarakat, (7) Program Bedah Rumah senilai 10 juta/unit, (8) Bantuan rehab masjid dan musholla, (9) Infaq untuk santri dan petugas majelis taklim setiap malam Jumat.

Kearifan, kedermawanan dan sikap demokrasi yang dimiliki Abdul Mukti membuat masyarakat dapat menerima pemikiran Abdul Mukti. Dalam berbagai ceramah, Abdul Mukti menyampaikan bahwa nasehatnya, tausiyahnya, ucapannya tidak mutlak dipercaya. Dalam masalah kedermawanan, bantuan Abdul Mukti kepada masyarakat cukup banyak. Bantuan bedah rumah yang diberikan mencapai ratusan rumah dengan nominal Rp. 10.000.000,00/unit. Begitu juga bantuan renovasi musholla di wilayah desa Koripan dan sekitarnya. Pemberian bantuan 
diberikan tanpa pandang bulu, tanpa pilih kasih yaitu kepada siapa saja, baik yang mengikuti pengajian maupun yang tidak. Bahkan bantuan renovasi masjid desa Koripan hingga saat ini sudah mencapai kurang lebih tiga milyar.

\section{Pemberdayaan Aspek Pendidikan}

Pondok pesantren An-Najach adalah sebuah pondok pesantren salaf. Pesantren ini mempertahankan tradisi salafiyahnya yaitu hanya mengajarkan ilmu-ilmu agama. Pondok pesantren An Najach menurut teori Mundzir Suparta termasuk tipe pesantren yang hanya mengajarkan ilmu-ilmu agama dalam bentuk madrasah diniah plus pesantren yang menyelenggarakan pengajian. Pondok pesantren An Najach memiliki 600 santri putra putri yang diharuskan tinggal di asrama.

\section{Pemberdayaan Aspek Ekonomi}

Aspek ekonomi merupakan bagian tidak kalah penting dalam proses pemberdayaan masyarakat berbasis majelis taklim. Bahkan sering dipandang sangat krusial dan menentukan serta menjadi pusat perhatian. Para warga sekitar memanfaatkan majelis taklim untuk berdagang di sekitar pondok pesantren An Najach. Acara pengajian yang selalu ramai dan penuh oleh jamaah membuat daya tarik ratusan pedagang. Sepanjang jalan raya menuju lokasi pengajian terdapat ratusan lapak berjejer yang menjual berbagai barang, warung makan, sayuran, pakaian, peralatan rumah tangga, buah-buahan, mainan anak, dan lainlain.

Suasana pengajian di sekitar pondok berubah menjadi pasar. Warung makan adalah lapak yang paling banyak dikunjungi jamaah. Hal ini dapat dimaklumi karena jamaah yang hadir jumlahnya ribuan dan meraka butuh sarapan dan makan malam. Ratusan pedagang terdiri dari laki-laki, perempuan, tua, muda, anak-anak, grosir, eceran, Jawa, Madura, Padang, Betawi dan sebagainya berbaur dan berdagang sambil mengaji. Pasar tiban ini bebas terbuka untuk umum tanpa biaya pajak maupun retribusi. 


\section{Penutup}

Majelis taklim An Najach Magelang selalu diikuti ribuan jamaah yang berdatangan dari berbagai kota dan terdiri dari berbagai lapisan dan latar belakang masyarakat. Majelis taklim An Najach berorientasi pada pengajaran dan pengamalan ajaran Islam dalam praktik kehidupan sehari-hari, baik sebagai individu maupun kelompok. Sebagian besar materi ceramah bersifat umum (tanpa gradasi atau spesifikasi) dan berorientasi pada kesalehan individu, perilaku ajaran tasawuf, dan dakwah amar ma'ruf nahi munkar.

Nilai-nilai multikultural banyak ditemukan dalam materi pengajian majelis taklim An Najach yang meliputi kesetaraan pendidikan, pedagogi kritis, dan dedikasi pengalaman pendidikan, kesederajatan (egalitarianism), pengakuan, penghargaan dan keadilan terhadap hak-hak individu maupun komunitasnya, kesetaraan (equality), kritis terhadap perbedaan status sosial, memberikan prinsip- prinsip demokratis, dan keadilan sosial, berlomba berbuat baik (competition in good works), memaafkan orang lain (forgiveness toward humankind), pendidikan tentang kehidupan bersama (living together), menumbuhkan sikap saling percaya (mutual trust), saling menghargai (mutual respect), berpikir positif (positive thinking), kedamaian (peace), terbuka dalam berfikir, menjunjung tinggi agama dan mengembangkan potensi religius, moral, intelektual, ekonomi, sosial, kesopanan dan budaya.

Majelis taklim An Najach juga menyampaikan cermah intoleransi dan nilai-nilai anti-multikulturalisme, semacam klaim kebenaran, prasangka/ prejudice dan stereotip, stigma dan penghakiman, arogansi kelompok dan hatred speeches atau ceramah mengandung pesan kebencian. Intoleransi Abdul Mukti dalam majelis taklim An Najach adalah ketidak-mampuannya menahan diri tidak suka kepada orang lain, sikap mencampuri dan atau menentang sikap atau keyakinan orang lain yang diungkapkan dalam ceramahnya, akan tetapi tidak mengganggu orang lain. Sikap intoleransi Abdul Mukti tersebut disebabkan oleh simplifikasi-palsu atau "prasangka yang berlebihan" (over generalized beliefs) yang mencakup stereotip terhadap "orang lain yang direndahkan", sikap muak atau tidak suka yang mendalam akan tetapi tidak melakukan tindakan negatif terhadap anggota kelompok lain, baik secara interpersonal maupun 
dalam hal kebijakan politik-sosial.

Dalam pemberdayaan masyarakat, majelis taklim An Najach mampu memberdayakan masyarakat dalam berbagai macam aspek. Keberadaan majelis taklim An Najach memberikan kebermanfaatan bagi kehidupan masyarakat yaitu memberdayakan masyarakat dalam aspek spiritual, sosial, ekonomi, dan pendidikan. Pemberdayaan tersebut diperuntukkan bagi seluruh masyarakat tanpa terkecuali.

\section{Daftar Pustaka}

Afriadi 2018. Tesis UIN Raden Intan Lampung (Peranan Majelis Taklim Dalam Pemberdayaan Masyarakat Islam di Desa Paya Benua Kecamatan Mendo Barat Bangka Belitung. URL:http:// repository.radenintan.ac.id/id/eprint/2535)

Alfisyah. 2009. "Pengajian dan Transformasi Sosiokultural dalam Masyarakat Muslim Tradisionalis Banjar". KOMUNIKA, Jurnal Dakwah dan Komunikasi, Vol.3 No.1 Januari-Juni: 75-89.

Amin, Nasihun. 2016. "Peran Sosial Majlis Taklim: Perintisan Majlis Taklim Az-Zahra, Gondoriyo, Ngaliyan Sebagai Lembaga Amil Zakat". DIMAS - Volume 16, Nomor 2, November: 291-305.

Arifin, M. 1993. Kapita Selekta Pendidikan, Islam dan Umum. Jakarta: Bumi Aksara.

Asrohah, Hanun. 1999. Sejarah Pendidikan Islam. Jakarta: Logos.

Baidhawy, Zakiyuddin. 2005. Pendidikan Agama Berwawasan Multikultural. Jakarta: Erlangga.

Baidhowi, Zakiyuddin. 2010. "The Problem Of Multiculturalism: Radicalism Mainstreaming through Religious Preaching in Surakarta”. Journal of Indonesian Islam. Vol. 4, No 2: 268. http://jiis.uinsby.ac.id/index.php /JIIs/article/view/

Banks, James A. 1993. Multicultural Education: Historical Development, Dimensions, And Practice: Review of Research in Education.

Blum, Lawrence A. 2001. "Antirasisme, Multikulturalisme, dan Komunitas antar Ras: Tiga Nilai yang Bersifat Mendidik bagi Sebuah Masyarakat Multikultural", dalam Larry May, Etika Terapan I Sebuah Pendekatan Multikultural, edisi terj. Sinta Carolina, dkk. Jogjakarta: Tiara Wacana. 
Boland, BJ. 1997. The struggle of Islam in Modern Indonesia. The Hague: Martinus Nijhoff.

Cohen, Andre Jason. 2004. "What Toleration Is". Ethics, The University of Chicago Journals. Vol. 115, No. 1 (October): 6895. DOI: $10.1086 / 421982$.

Djazilan, Syukron. 2019. "Proses Sosialisasi dan Internalisasi NilaiNilai Ke-Islaman pada Kelas Menengah Muslim di Surabaya". Education and Human Development Journal, Volume 4. Nomor 1. April: 35-48. DOI: 10.15640/jehd.

Gollnick, Donna M. 1983. "Culture and Pluralism”, dalam Donna M. Gollnick dan Philip Chinn, Multicultural Education in Pluralistic Society. London: The CV Mosby Company.

Gorski, Paul C. 2010. The Challenge Of Defining'Multicultural Education. www. edchange.org/ multicultural/initial.html.

Hamid, Harizah. 1991. Majelis Taklim. Jakarta: Bulan Bintang.

Hasbullah. 1995. Sejarah Pendidikan Islam di Indonesia. Jakarta: Rajawali.

Huda, Nurul, dkk,. 1984. Pedoman Majelis Taklim. Jakarta: Proyek Penerangan Bimbingan Dakwah Khutbah Agama Islam Pusat.

Hunsberger. 1995. Religion, Intolerance, and Conflict: A Scientific and Conceptual Investigation. Oxford University Press.

Jadidah, Amatul. 2016. "Paradigma Pendidikan Alternatif: Majelis Taklim Sebagai Wadah Pendidikan Masyarakat." LP3M IAI Al-Qolam, JURNAL PUSAKA, Vol. 7. 111-123 p-ISSN 23392215 .http://ejournal.alqolam.ac.id/index.php/jurnal_ pusaka/ issue/archive.

Kymlicka, Will. 1999. "Misunderstanding Nationalism" dalam Theorizing Nationalism, ed. R. Beiner, Albany: State University of New York.

Laxmana, Galuh Andy. 2018. http://kendal.muhammadiyah.or.id/ berita-14763-detail-pengajian-ahad-pagi-weleri-ibnu-sholehjalani-hidup-ini-dengan-positif.html

Ledang, Irwan. 2016. "Tradisi Islam dan Pendidikan Humanisme: Upaya Transinternalisasi Nilai Karakter Dan Multikultural Dalam Resolusi Konflik Sosial Masyarakat Di Indonesia”. 
Jurnal Kajian Islam Interdisiplin. Vol. 1 Nomor 1, Juni: 105-124. http://ejournal.uin-suka.ac.id/pasca/jkii/article/view/1056.

Liliweri, Alo. 2005. Prasangka dan Konflik: Komunikasi Lintas Budaya Masyarakat Multikultur. Yogyakarta: LKIS.

Mahfud, Choirul. 2006. Pendidikan Multikultural. Yogyakarta: Pustaka Pelajar.

Maulana, Dirga. 2017. "Exclusivism of Religion Teachers: Intolerance and Radicalism in Indonesian Public Schools". Studia Islamika, Vol. 24, No. 2: 395. DOI: 10.15408/sdi.v24i2.5707.

Miftah, Muhammad. 2016. "Multicultural Education In The Diversity of National Cultures". QIJIS: Qudus International Journal of Islamic Studies. Volume 4, Issue 2, August: 167-185. . DOI: 10.21043/qijis.v4i2.1766.

Minangsih, Kalsum. 2014. "New Paradigm in Dakwa Institutional Arrangement: The Urgency of Management Science to Improve the Ideal Majelis Taklim". Kontekstualita, Vol. 29, No. 2: 145155.

Moleong, Lexi J. 2008. Metodologi Penelitian Kualitatif. Bandung: Remaja Rosdakarya.

Nakaya, Ayami. 2018. "Overcoming Ethnic Conflict through Multicultural Education: The Case of West Kalimantan, Indonesia". International Journal of Multicultural Education. Vol. 20, No. 1: 118-133. DOI: http://dx.doi.org/10.18251/ ijme. v20i1.1549.

Nashrul, Erdy. 2018. https://khazanah.republika.co.id/berita/duniaislam/islam-digest/18/02/27/ p4suiq313-memahami-istilahmajelis-taklim.

Poston, Larry. 1992. Islamic Dakwah in the West: Muslim Missionary Activity and Dinamic of Conversion. New York: Oxford University Press.

Powell, Russell \& Clarke, Steve. 2013. Religion, Tolerance and Intolerance: Views from Across the Disciplines. Oxford University Press.

Qorib, Muhammad. 2018. "Dakwah Di Tengah Pluralitas Masyarakat". 